\title{
Antioxidant activity of protein extracts from heat-treated or thermally processed chickpeas and white beans
}

\author{
Iskender Arcan ${ }^{\mathrm{b}}$, Ahmet Yemenicioğlu ${ }^{\mathrm{a}, *}$ \\ a Department of Food Engineering, Faculty of Engineering, Izmir Institute of Technology, 35430, Gülbahçe Köyü, Urla, Izmir, Turkey \\ ${ }^{\mathrm{b}}$ Biotechnology and Bioengineering Program, Izmir Institute of Technology, 35430 Gülbahçe Köyü, Urla, Izmir, Turkey
}

Received 30 January 2006; received in revised form 28 March 2006; accepted 26 July 2006

\begin{abstract}
In this study, antioxidant activities of water-soluble protein extracts from chickpeas and white beans were investigated. The area under the curve (AUC) values of lyophilized crude protein extracts (dialyzed or undialyzed) from thermally processed (121 ${ }^{\circ} \mathrm{C}$ for $20 \mathrm{~min})$ or heat-treated $\left(90^{\circ} \mathrm{C}\right.$ for $\left.20 \mathrm{~min}\right)$ chickpeas $(73-91 \mu \mathrm{mol}$ trolox/g) and white beans $(39-67 \mu \mathrm{mol}$ trolox/g) indicated a higher free radical-scavenging capacity and thermostability for chickpea proteins than for white bean proteins. The thermal processing also increased the $\mathrm{Fe}^{+2}$-chelating capacity of lyophilized chickpea crude protein extracts 1.8 -fold whereas it caused a 2.3 -fold reduction in the $\mathrm{Fe}^{+2}$-chelating capacity of lyophilized white bean crude protein extracts. Dialysis increased the protein content of lyophilized chickpea extracts 1.5-2-fold but it did not affect the protein content of lyophilized white bean extracts significantly. Ammonium sulfate precipitation was not effective for selective precipitation of antioxidant proteins. However, it improved the free radical-scavenging capacity of lyophilized protein extracts from thermally processed chickpeas and white beans by almost 25\% and 100\%, respectively. DEAE-cellulose chromatography, indicated the presence of five $\left(A_{1}-A_{5}\right)$ and three $\left(B_{1}-B_{3}\right)$ antioxidant protein fractions in heat-treated and thermally processed chickpea protein extracts, respectively, and can be used for the partial purification of antioxidant proteins. The results of this study showed the good potential of chickpea proteins as thermostable natural food antioxidants.
\end{abstract}

(C) 2006 Elsevier Ltd. All rights reserved.

Keywords: Legumes; Proteins; Radical scavenging; Antioxidant activity; Thermal stability

\section{Introduction}

Due to health concerns of consumers, extensive research has been conducted on natural antioxidants, such as protein or phenolic extracts and vitamins $\mathrm{E}$ and $\mathrm{C}$, in place of synthetic antioxidants, such as butylated hydroxyanisole (BHA) and butylated hydroxytoluene (BHT) (Moore et al., 2003; Rajalakshmi \& Narasimhan, 1996; Vermeiren, Devlieghere, van Beest, de Kruijf, \& Debevere, 1999; Wu, Weller, Hamouz, Cuppett, \& Schnepf, 2001). The natural antioxidants are readily accepted by consumers and do not require safety tests if they are components of food that

\footnotetext{
${ }^{*}$ Corresponding author. Tel.: +90 232 7506292; fax: +90 2327506196. E-mail address: ahmetyemenicioglu@iyte.edu.tr (A. Yemenicioğlu).
}

are generally recognized as safe (GRAS) (Rajalakshmi \& Narasimhan, 1996).

Recently, the use of natural protein extracts or purified proteins as antioxidants has attracted particular interest. Many food proteins, including milk proteins, such as lactoferrin, $\beta$-lactoglobulin and casein, soy proteins, mushroom proteins, egg albumen proteins and egg yolk phosvitin, maize zein, potato patatin and yam dioscorin, were reported to have antioxidant activity (Chiue, Kusano, \& Iwami, 1997; Hou et al., 2001; Kouoh et al., 1999; Liu, Han, Lee, Hsu, \& Hou, 2003; Maheswari, Ramadoss, \& Krishnaswamy, 1997; Rajalakshmi \& Narasimhan, 1996; Satue-Gracia, Frankel, Rangavajhyala, \& German, 2000; Zhao et al., 2004). The proteins owe their antioxidant activity to their constituent amino acids. For example, the antioxidant activities of aromatic amino acids such as 
tyrosine, phenylalanine and tryptophan and the sulfur-containing amino acid, cysteine, are due to their ability to donate protons to free radicals $(\mathrm{Hu}$, McClements, \& Decker, 2003; Je, Park, \& Kim, 2004; Rajapakse, Mendis, Jung, Je, \& Kim, 2005) whereas basic amino acids, such as lysine and arginine, and acidic amino acids, such as aspartate and glutamate, exercise antioxidant activity by chelating metal ions (Rajapakse et al., 2005; Saiga, Tanabe, \& Nishumura, 2003). It was reported that the basic amino acid, histidine, may behave both as a radical-scavenger and a metal-chelator due to its imidazole ring ( $\mathrm{Je}$ et al., 2004; Rajapakse et al., 2005). However, the presence of some antioxidant amino acids in sequence is not the only factor that determines the antioxidative properties of proteins. The correct positioning of the amino acids in a protein sequence is also a very important factor, and effective for antioxidant activity (Chen, Muramoto, Yamauchi, \& Nokihara, 1996; Rajapakse et al., 2005). For example, peptides having proline at the $\mathrm{N}$-terminus more effectively prevent oxidation of linoleic acid than do peptides having proline at the C-terminus (Chen et al., 1996). Also, peptides having histidine residues at the $\mathrm{N}$-terminus show higher metal-chelating activity than do peptides having histidine at the C-terminus (Chen, Muramoto, Yamauchi, Fujimoto, \& Nokihara, 1998). It has also been reported that there is a close relationship between the hydrophobicity and antioxidant activity of proteins and peptides (Chen, Muramoto, \& Yamauchi, 1995; Chiue et al., 1997; Rajapakse et al., 2005; Saiga et al., 2003). For example, the antioxidant activity of the hydrophobic protein, zein, has been attributed to its ability to bind and bury unsaturated lipids (Chiue et al., 1997). Moreover, Hu et al. (2003) reported that the cationic characteristics of proteins are also important for their antioxidant activity since positively charged groups help inhibition of lipid oxidation by electrostatic repulsion of transition metals away from the lipid droplets. Thus, it seems that, besides their free radical-scavenging and iron-binding activities, proteins also prevent lipid oxidation by isolating lipids from free radicals and metal ions.

Other advantages of using proteins as antioxidant substances in food systems are their additional functions, such as nutritive value, emulsifying activity, antimicrobial activity, foam and gel formation, flavour binding, increase of viscosity or film formation. For example, besides their antioxidant activity, proteins, such as casein and bovine serum albumin, and protein isolates, such as whey protein isolate and soy protein isolate, are well known for their emulsifying activity (Al-Malah, Azzam, \& Omari, 2000; Fukuzawa et al., 2005; Hu et al., 2003; Kouoh et al., 1999; Pearce \& Kinsella, 1978). Calcium caseinate and whey proteins can form edible films with antioxidant activity (Le Tien, Vachon, Mateescu, \& Lacroix, 2001). Lactoferrin and phosvitin are proteins that show both antioxidant and antimicrobial activity (Huang, Satue-Gracia, Frankel, \& German, 1999; Khan et al., 2000; Maheswari et al., 1997; Liceaga-Gesualdo, Li-Chan, \& Skura, 2001; Recio \& Visser, 2000; Satue-Gracia et al., 2000).
In plants and animals, the major water-soluble protein fraction is formed by albumins (Damodaran, 1996). In the literature, the antioxidant activities of albumins from legumes, such as broad beans, white and brown beans and light peas (Okada \& Okada, 1998; Wolosiak \& Klepacka, 2002) and bovine and human serum (Aime et al., 2003; Fukuzawa et al., 2005; Kouoh et al., 1999; Wolosiak \& Klepacka, 2002), have been well documented. The emulsifying and foaming activity of animal and plant origin albumins has also been reported by different workers (AlMalah et al., 2000; Burnett et al., 2002; Damodaran, 1996; Ma \& Harwalkar, 1984; Pearce \& Kinsella, 1978; Tong, Sasaki, McClements, \& Decker, 2000). In the literature, no studies have been reported on the antioxidant activity of chickpea albumins. The effect of thermal processing on antioxidant activity of legume albumins has also not been investigated. Chickpea protein quality is higher than that of common bean (Freidman, 1996). Chickpeas also contain lower amounts of toxic and antinutritive factors than do the common beans (Hernandez-Infante, Sousa, Montalvo, \& Tena, 1998). Thus, in this study, to evaluate the antioxidant activity and thermostability of chickpea albumins, we have compared the free radicalscavenging and iron-binding capacities of crude or partially purified water-soluble protein extracts from heat-treated or thermally processed chickpeas and white beans. The antioxidant protein fractions of protein extracts from chickpeas were also separated by anion-exchange chromatography and their free radical-scavenging capacities were determined.

\section{Materials and methods}

\subsection{Materials}

Dried chickpeas (cv. Koçbaşı) and white beans (cv. Dermason) were purchased from a supermarket in Izmir (Turkey). The dialysis tubing $(12,000 \mathrm{MW}$, prepared as described in the product manual), bovine serum albumin (fraction V), DEAE-cellulose (fast flow column, prepared as described in the product manual), insoluble PVPP (polyvinylpolypyrrolidone), ABTS (2,2-azino-bis-(3-ethylbenzthiazoline-6-sulfonic acid)), linoleic acid (99\%) and Tween 20 were purchased from Sigma Chem. Co. (St. Louis, Mo., USA). Ammonium sulfate (for biochemistry) was purchased from Merck (Darmstadt). Trolox and Ferrous chloride tetrahydrate were purchased from Fluka (Switzerland). Ferrozine (3-(2-pyridyl)-5,6-diphenyl-1,2,4-triazine$4^{\prime}, 4^{\prime \prime}$-disulfonic acid monosodium salt) was purchased from Fluka (USA). Sericin (Silk Biochemical Co. Ltd, Japan) was kindly donated by Assistant Professor Dr. Oğuz Bayraktar from Izmir Institute of Technology, Izmir, Turkey.

\subsection{Heat-treatment of legumes}

Heat-treatment was specifically applied for the inactivation of lipoxygenase (LOX), the enzyme responsible for the 
oxidation of lipids in food. To prepare the samples, the legumes were first rehydrated in distilled water for $12 \mathrm{~h}$ at room temperature. The samples were then put into sacks made from cheesecloth and heated at $90{ }^{\circ} \mathrm{C}$ for $5,10,15$ or $20 \mathrm{~min}$. The suitable heating period was determined to be $20 \mathrm{~min}$, by considering the residual activities of LOX in heated chickpeas (LOX inactivated in $5-10 \mathrm{~min}$ at $90^{\circ} \mathrm{C}$ ) and white beans (LOX inactivated in 15-20 min at $90^{\circ} \mathrm{C}$ ). The LOX activity was assayed in water extracts of legume homogenates by using linoleic acid dissolved by Tween 20, as described by Yemenicioğlu, Özkan, Velioğlu, and Cemeroğlu (1998).

\subsection{Thermal processing of legumes}

Thermal processing was applied to compare the thermostabilities of antioxidant proteins in chickpeas and white beans. It was supposed that thermal processing might be needed to obtain microbiologically stable protein extracts with reduced antinutrients and allergens that exist in most legumes (Hernandez-Infante et al., 1998). For the preparation of thermally processed samples, the legumes were put into flasks containing distilled water and thermally processed at $121{ }^{\circ} \mathrm{C}$ for $20 \mathrm{~min}$. The treated samples were then cooled and processed immediately to acetone powder.

\subsection{Preparation of acetone powders}

To remove phenolic compounds and lipids, acetone powders were used as sources of protein extracts. For the preparation of acetone powders, heat-treated or thermally processed chick peas or white beans (prepared initially from $50 \mathrm{~g}$ dry sample) were homogenized in a Waring blender for $3 \mathrm{~min}$ with $200 \mathrm{ml}$ of cold acetone. The slurry obtained was filtered under vacuum through a Buchner funnel containing a Whatman No:1 filter paper and the residue remaining on the filter paper was collected. The homogenization with $200 \mathrm{ml}$ acetone and filtration were then repeated twice more for the collected residue and the powder, left overnight to evaporate the acetone, was stored at $-18^{\circ} \mathrm{C}$ until it was used in the extraction.

\subsection{Preparation of crude protein extracts}

To prepare the water-soluble crude protein extracts from heat-treated or thermally processed chickpeas or white beans, the extraction method given by Genovese and Lajolo (1998) was applied with minor modifications. Briefly, $20 \mathrm{~g}$ of acetone powder, $0.5 \mathrm{~g}$ of insoluble PVPP (used to absorb possible residual phenolic compounds) and $180 \mathrm{ml}$ of distilled water were mixed and extracted with a magnetic stirrer for $2 \mathrm{~h}$ at room temperature. The extract was then filtered through 4-layers of cheesecloth to collect the filtrate and the cake was discharged. The filtrate was centrifuged at $15,000 \mathrm{~g}$ for $30 \mathrm{~min}$ at $4{ }^{\circ} \mathrm{C}$ and the supernatant was dialyzed for $72 \mathrm{~h}(48 \mathrm{~h}$ against $5 \times 21$ of distilled water and $24 \mathrm{~h}$ against $3 \times 21$ of deionized water) at $4{ }^{\circ} \mathrm{C}$. After dialysis, the extract was clarified by centrifugation at $4500 \mathrm{~g}$ for $15 \mathrm{~min}$ at $4{ }^{\circ} \mathrm{C}$ and lyophilized and stored at $-18^{\circ} \mathrm{C}$ until it was used for antioxidant activity determination. The lyophilization was conducted by using a freeze-drier (Labconco, FreeZone, 61, Kansas City, MO, USA) working between -44 and $-47^{\circ} \mathrm{C}$ for collector temperature and $50 \times 10^{-3}$ and $100 \times 10^{-3} \mathrm{mBar}$ vacuum.

\subsection{Partial purification of crude protein extracts by ammonium sulfate precipitation}

For partial purification, solid ammonium sulfate was added slowly to crude protein extracts, obtained as described in Section 2.5, without applying $72 \mathrm{~h}$ of dialysis. The addition of ammonium sulfate was conducted at $4{ }^{\circ} \mathrm{C}$ up to $90 \%$ saturation. The mixture was then stirred slowly for $1.5 \mathrm{~h}$ at $4{ }^{\circ} \mathrm{C}$ and the precipitate obtained by centrifugation at $15,000 \mathrm{~g}$ for $30 \mathrm{~min}$ at $4{ }^{\circ} \mathrm{C}$ was dissolved in $20 \mathrm{ml}$ of distilled water. The extract was then dialyzed for $36 \mathrm{~h}$ (against $4 \times 21$ of distilled water) at $4{ }^{\circ} \mathrm{C}$, clarified by centrifugation at $15,000 \mathrm{~g}$ for $30 \mathrm{~min}$ at $4{ }^{\circ} \mathrm{C}$ and lyophilized and stored at $-18^{\circ} \mathrm{C}$.

\subsection{Purification of antioxidant protein fractions by DEAE- cellulose chromatography}

Crude protein extracts were obtained as described in Section 2.5 with a $72 \mathrm{~h}$ dialysis. Following dialysis, the extracts were once more centrifuged at $4500 \times \mathrm{g}$ for 15 min at $4{ }^{\circ} \mathrm{C}$ and loaded onto a DEAE-cellulose fast-flow column $(2.4 \mathrm{~cm}$ diameter, $10 \mathrm{~cm}$ height $)$, previously equilibrated with $0.01 \mathrm{M}$ Na-phosphate buffer, $\mathrm{pH}$ 7.0. The washing of the column was conducted with $300 \mathrm{ml}$ of equilibration buffer and it was then eluted with a continuous linear gradient of $0-1.5 \mathrm{M} \mathrm{NaCl}$ prepared in $0.01 \mathrm{M} \mathrm{Na}$ phosphate buffer at $\mathrm{pH}$ 7.0. Fractions $(5 \mathrm{ml})$ collected from the column were assayed for their antioxidant activity against ABTS free radical, as described in Section 2.8. However, the inhibition period of tests for collected fractions was shortened to $2 \mathrm{~min}$ to complete the measurements of all samples as soon as possible and prevent possible changes in the antioxidant properties of proteins. The protein content of the fractions was also monitored by measuring absorbance value at $280 \mathrm{~nm}$. After determination of the profiles of antioxidant activity and protein, the most active fractions of separated proteins were combined and once more tested for antioxidant activity. However, the test period of these samples was set to $15 \mathrm{~min}$ and their total antioxidant activities in purification tables were expressed as trolox equivalents $(\mu \mathrm{mol})$. The specific antioxidant activity was calculated by dividing total antioxidant activity by protein content, determined by the Lowry method. The obtained protein fractions were then dialyzed for $24 \mathrm{~h}$ (against $3 \times 21$ of distilled water) at $4{ }^{\circ} \mathrm{C}$ and lyophilized and stored at $-18{ }^{\circ} \mathrm{C}$. 


\subsection{Determination of free radical-scavenging activity}

The free radical-scavenging activity was determined, as described in Re et al. (1999), by using ABTS free radical prepared by oxidation with potassium persulfate. The reaction mixtures for the measurements were formed by mixing $0.1 \mathrm{ml}$ of protein solution or extract and $1.9 \mathrm{ml}$ of ABTS free radical solution diluted with PBS (initial absorbance at $734 \mathrm{~nm}$ was almost 0.7 ). The discoloration of dark blue-coloured ABTS free radical by the antioxidant protein was monitored at $734 \mathrm{~nm}$ for $15 \mathrm{~min}$. All measurements were performed in triplicate. The free radical-scavenging capacities of samples were determined by dividing the area of their inhibition of ABTS free radical (\%)/concentration $(\mu \mathrm{g} /$ reaction mixture) ratio vs. period of inhibition test $(1,6$ and $15 \mathrm{~min}$ ) curves by that area of the same curve of the standard antioxidant, trolox. The area under the curve value (AUC) determined by this method represents the free radical-scavenging capacity as $\mu \mathrm{mol}$ trolox per $\mathrm{g}$ of lyophilized protein extract. Bovine serum albumin and sericin were used as standard proteins for comparison of antioxidant activities.

\subsection{Determination of $\mathrm{Fe}^{+2}$-chelating capacity}

The $\mathrm{Fe}^{+2}$-chelating capacities of protein extracts were determined as described in Rajapakse et al. (2005) with minor modifications. Briefly, $2 \mathrm{ml}$ of protein solution was mixed with $0.1 \mathrm{ml}$ of $1 \mathrm{mM} \mathrm{FeCl} \mathrm{F}_{2} .4 \mathrm{H}_{2} \mathrm{O}$ solution. After $30 \mathrm{~min}$ incubation at room temperature, $0.1 \mathrm{ml}$ of $0.5 \mathrm{mM}$ ferrozine was added to the mixture and its absorbance was read at $562 \mathrm{~nm}$ after a $10 \mathrm{~min}$ incubation. The percent $\mathrm{Fe}^{+2}$-chelating activities of samples were determined by using deionized water in place of sample. The $\mathrm{Fe}^{+2}$-chelating capacities of samples were determined by dividing the slope of the initial linear portion of their $\mathrm{Fe}^{+2}$-chelating capacity $(\%)$ vs. concentration $(\mu \mathrm{g} /$ reaction mixture) curves by that slope of the same curve of the chelating agent EDTA. The results were expressed as $\mu \mathrm{mol}$ EDTA per g of lyophilized extract. All measurements were performed in triplicate.

\subsection{Determination of protein content}

The protein contents of lyophilized samples and protein extracts were determined by the Lowry method, by using bovine serum albumin (BSA) as standard (Harris, 1987). The average of five measurements was used to calculate the protein content.

\section{Results and discussion}

\subsection{Water-soluble protein contents of lyophilized extracts}

Since extractions in this work were conducted with water, the proteins discussed in this study are mainly water-soluble albumins. In the literature, due to differences in the efficiency of extraction and separation of albumins and globulins, different reports exist on the albumin contents of legume proteins. For example, Bhatty (1982) reported that albumins form almost $12-13 \%$ of proteins in chickpeas and beans, whereas Genovese and Lajolo (1998) reported the albumin content of bean proteins to be $28 \%$.

As seen in Table 1, the lyophilized crude chickpea extracts contained 1.4-2.8-fold more soluble protein than did lyophilized crude white bean extracts obtained by the same procedures. The water-soluble protein content of lyophilized samples, changed between 0.15 and $0.51 \mathrm{~g} / \mathrm{g}$, indicated the presence of some impurities in the extracts other than proteins. In chickpeas and white beans, these substances are possibly carbohydrates such as soluble mono-, di- and oligosaccharides and colloidal starch and pectin (Garcia, Filisetti, Udaeta, \& Lajolo, 1998; Saini \& Knights, 1984; Sanchez-Mata, Penuela-Teruel, Camara-

Table 1

Free radical-scavenging capacity (AUC values) and water-soluble protein contents of different lyophilized protein extracts

\begin{tabular}{|c|c|c|c|}
\hline Process/sample name & Purification step(s) & Protein content $(\mathrm{g} / \mathrm{g})$ & AUC value $(\mu \mathrm{mol}$ trolox $/ \mathrm{g})$ \\
\hline \multicolumn{4}{|l|}{ Standard proteins } \\
\hline BSA & - & - & 36 \\
\hline Sericin & - & - & 148 \\
\hline \multicolumn{4}{|c|}{ Lyophilized chickpea protein extracts } \\
\hline Heat-treatment & Crude extract & 0.26 & 73 \\
\hline Heat-treatment & Dialyzed crude extract & 0.51 & 91 \\
\hline Thermal processing & Crude extract & 0.34 & 77 \\
\hline Thermal processing & Dialyzed crude extract & 0.51 & 82 \\
\hline Thermal processing & $\left(\mathrm{NH}_{4}\right)_{2} \mathrm{SO}_{4}$ precipitated dialyzed crude extract & 0.49 & 102 \\
\hline Heat-treatment & DEAE-cellulose purified $A_{2}$ fraction & - & 135 \\
\hline Thermal processing & DEAE-cellulose purified $\mathrm{B}_{2}$ fraction & - & 98 \\
\hline \multicolumn{4}{|c|}{ Lyophilized white bean protein extracts } \\
\hline Heat-treatment & Crude extract & 0.19 & 56 \\
\hline Heat-treatment & Dialyzed crude extract & 0.22 & 67 \\
\hline Thermal processing & Crude extract & 0.15 & 46 \\
\hline Thermal processing & Dialyzed crude extract & 0.18 & 39 \\
\hline Thermal processing & $\left(\mathrm{NH}_{4}\right)_{2} \mathrm{SO}_{4}$-precipitated dialyzed crude extract & 0.23 & 77 \\
\hline
\end{tabular}


Hurtado, Diez-Marques, \& Torija-Isasa, 1998). The high affinity of carbohydrates to legume albumins is well known (Genovese \& Lajolo, 1998). Thus, it is possible that some of these carbohydrates were bound ionically or covalently to proteins. Thermal processing increased the soluble protein content of lyophilized chickpea extracts. However, a slight reduction was observed in the soluble protein content of lyophilized white bean extracts after thermal processing. The application of dialysis caused 1.5-2.0-fold increase of soluble protein content in lyophilized crude protein extracts of chickpeas. The increase of protein content by the dialysis was related to the precipitation or removal of non-protein substances, such as carbohydrates, during this process. It is also possible than some of the proteins, particularly residual globulins, were also insolubilized and precipitated during dialysis. For this reason, in heat-treated chickpeas, the amount of lyophilized dry powder from dialyzed crude extract was $79 \%$ less than that from the undialyzed one. The precipitations also occurred during dialysis of white bean crude protein extracts. For example, in heat-treated white beans, the amount of lyophilized dry powder obtained from dialyzed crude extract was $49 \%$ less than that obtained from undialyzed crude extract. However, in white beans, the protein content of lyophilized extracts did not increase markedly after dialysis. It appears that dialysis caused the precipitation and/or removal of both protein and non-protein substances of white bean crude extracts.

\subsection{Free radical-scavenging capacity of lyophilized crude protein extracts}

The AUC values of lyophilized chickpea and white bean crude protein extracts (dialyzed or undialyzed) changed between 73 and $91 \mu \mathrm{mol}$ trolox/g and 39 and $67 \mu \mathrm{mol}$ trolox/g, respectively (Table 1). Thus, it is clear that the lyophilized crude protein extracts obtained from heat-treated or thermally processed chickpeas showed higher free radicalscavenging capacity than did those from heat-treated or thermally processed white beans (Figs. 1 and 2). In lyophilized chickpea crude protein extracts, no significant change occurred in the free radical-scavenging capacity after thermal processing. In contrast, the thermal processing reduced the free radical-scavenging capacity of lyophilized crude white bean protein extracts. In lyophilized crude protein extracts of heat-treated chickpeas and white beans and thermally processed chickpeas, dialysis increased the free radical-scavenging capacity slightly. However, the dialysis caused a reduction in the free radical-scavenging capacity of lyophilized crude extracts form thermally processed white beans. In the literature, it was reported that heating caused aggregation of bean albumins by different mechanisms, including the formation of disulfide bonds (Rocha, Genovese, \& Lajolo, 2002). Thus, it is likely that the aggregation by thermal processing reduced or masked some of the antioxidant groups in white bean proteins. It is also

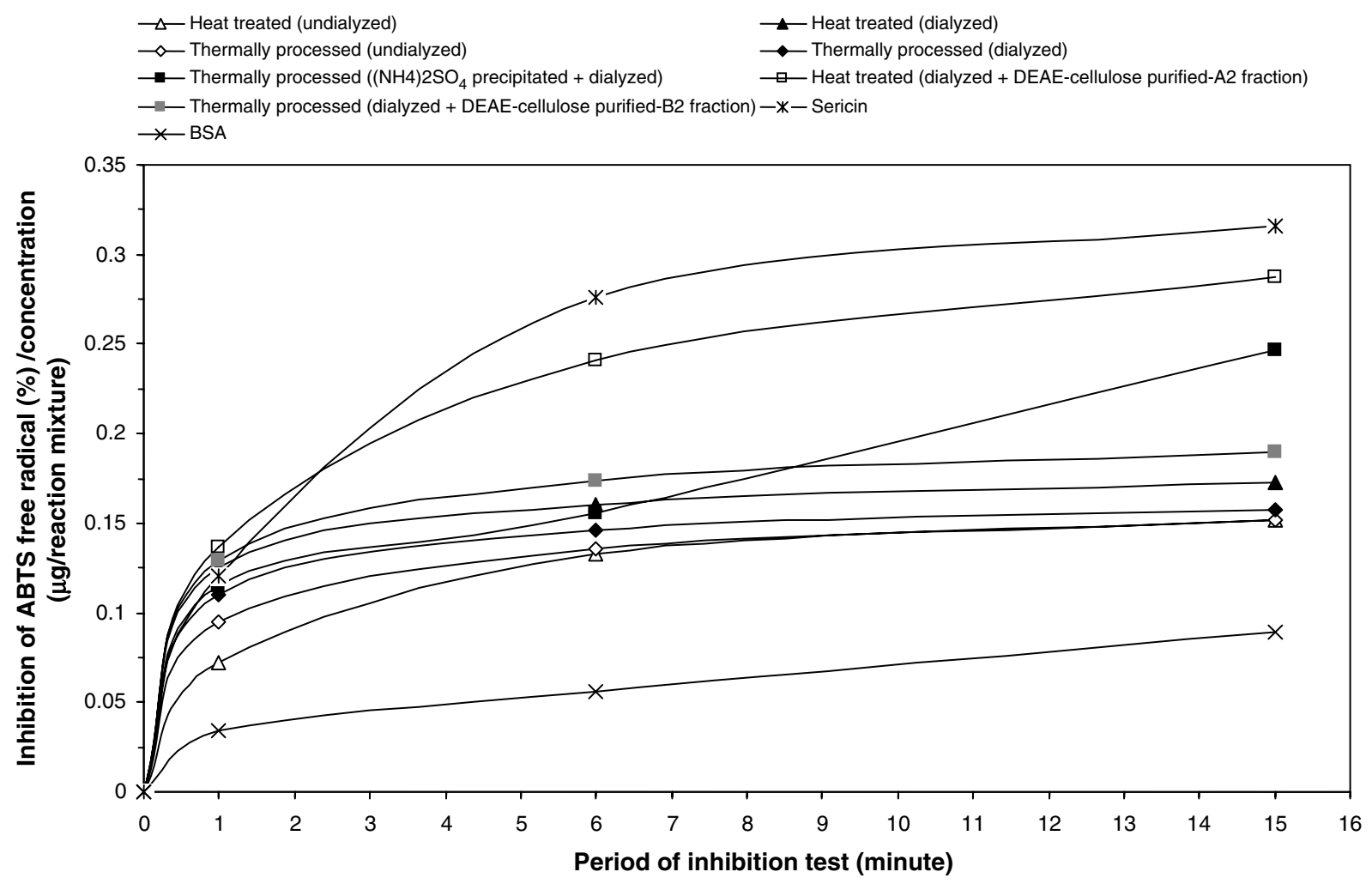

Fig. 1. Free radical-scavenging capacities of different lyophilized protein extracts from heat-treated or thermally processed chickpeas. 


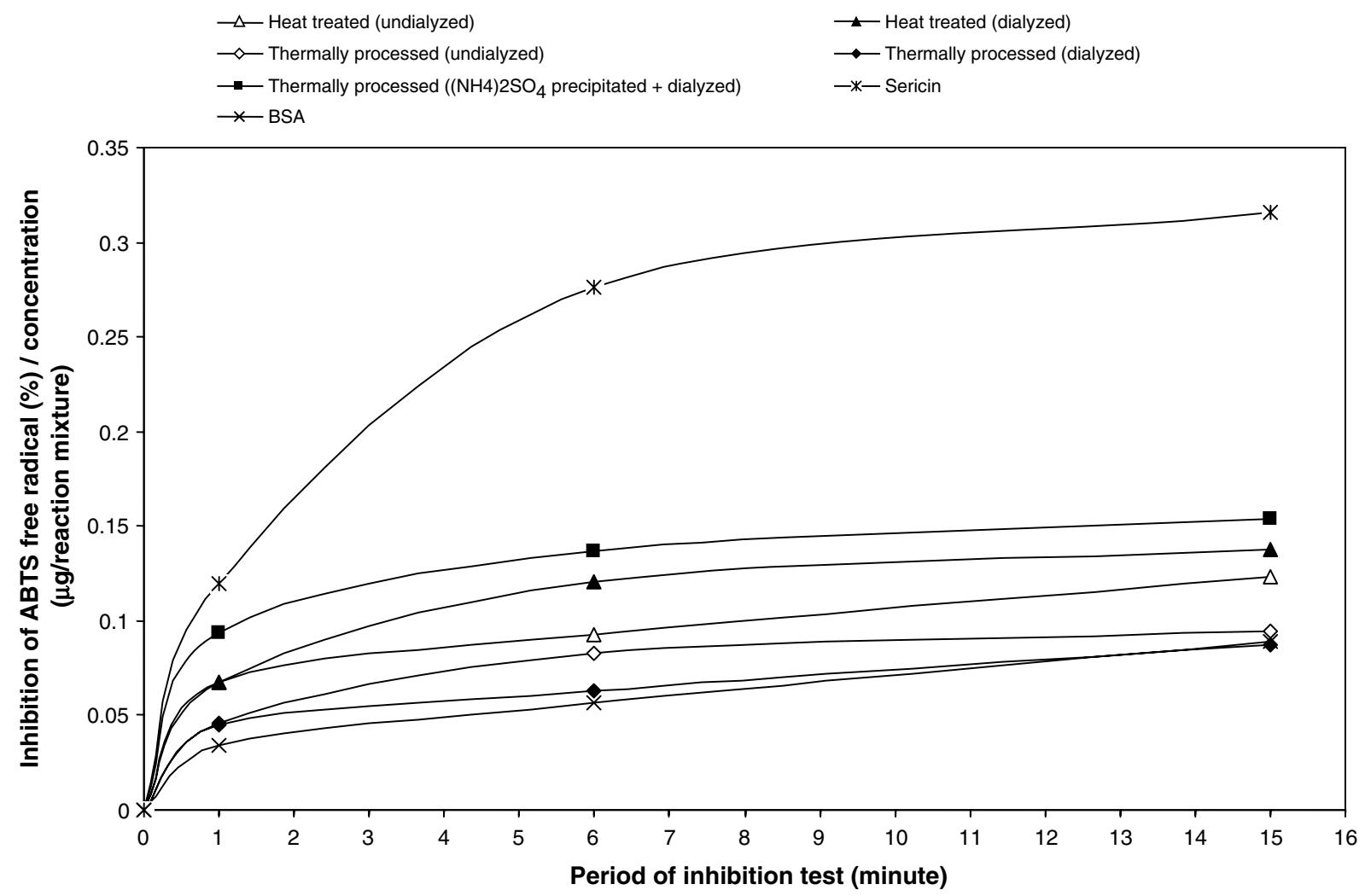

Fig. 2. Free radical-scavenging capacities of different lyophilized protein extracts from heat-treated or thermally processed white beans.

possible that some of the antioxidant proteins lost their solubility and precipitated during extraction and dialysis.

On the other hand, the AUC values also showed that the lyophilized crude chickpea and white bean protein extracts (dialyzed or undialyzed) had 2-2.5- and 1.1-1.9-fold higher antioxidant activity than had BSA, respectively. However, both lyophilized crude chickpea and white bean extracts showed lower antioxidant activity than did the sericin, an antioxidant protein patented for food applications (Yamada, Fuwa, \& Nomura, 2000).

\section{3. $\mathrm{Fe}^{+2}$-chelating capacity of lyophilized crude protein extracts}

As seen in Table 2, all lyophilized preparations obtained from dialyzed crude protein extracts showed $\mathrm{Fe}^{+2}$-chelating activity. In fact, this was expected since $50 \%$ and $40 \%$ of amino acids in chickpea and dry bean albumins are metalchelating amino acids, namely lysine, arginine, aspartic acid, glutamic acid and histidine, respectively (Bhatty, 1982). In lyophilized crude protein extracts of chickpeas, the $\mathrm{Fe}^{+2}$-chelating capacity increased almost 1.8 -fold by thermal processing. In contrast, thermal processing reduced the $\mathrm{Fe}^{+2}$-chelating capacity of lyophilized crude protein extracts of white beans almost 2.3 -fold. This result once more confirmed the significantly different thermostabilities of antioxidant components in chickpeas and white beans. It seems that the conformational changes caused by thermal processing increased accessibility to metal chelating groups of chickpea proteins while it reduced the accessibility of metal-chelating groups in white bean proteins. On the other hand, sericin did not show a marked $\mathrm{Fe}^{+2}$-chelating activity. Also, except for the lyophilized preparations obtained from thermally processed white beans, all lyophilized crude

Table 2

$\mathrm{Fe}^{+2}$-chelating capacities of different lyophilized protein extracts

\begin{tabular}{|c|c|}
\hline Process/sample name & $\mathrm{Fe}^{+2}$-chelating capacity $(\mu \mathrm{mol}$ EDTA/g) \\
\hline BSA & $30(0-3000)^{\mathrm{a}}$ \\
\hline Sericin & $3(0-3000)$ \\
\hline Heat-treated chickpeas (dialyzed crude extract) & $50(0-1500)$ \\
\hline Thermally processed chickpeas (dialyzed crude extract) & $90(0-600)$ \\
\hline Heat-treated white beans (dialyzed crude extract) & $70(0-600)$ \\
\hline Thermally processed white beans (dialyzed crude extract) & $30(0-1500)$ \\
\hline
\end{tabular}

\footnotetext{
a The concentration range of data used to calculate the $\mathrm{Fe}^{+2}$-chelating capacity.
} 


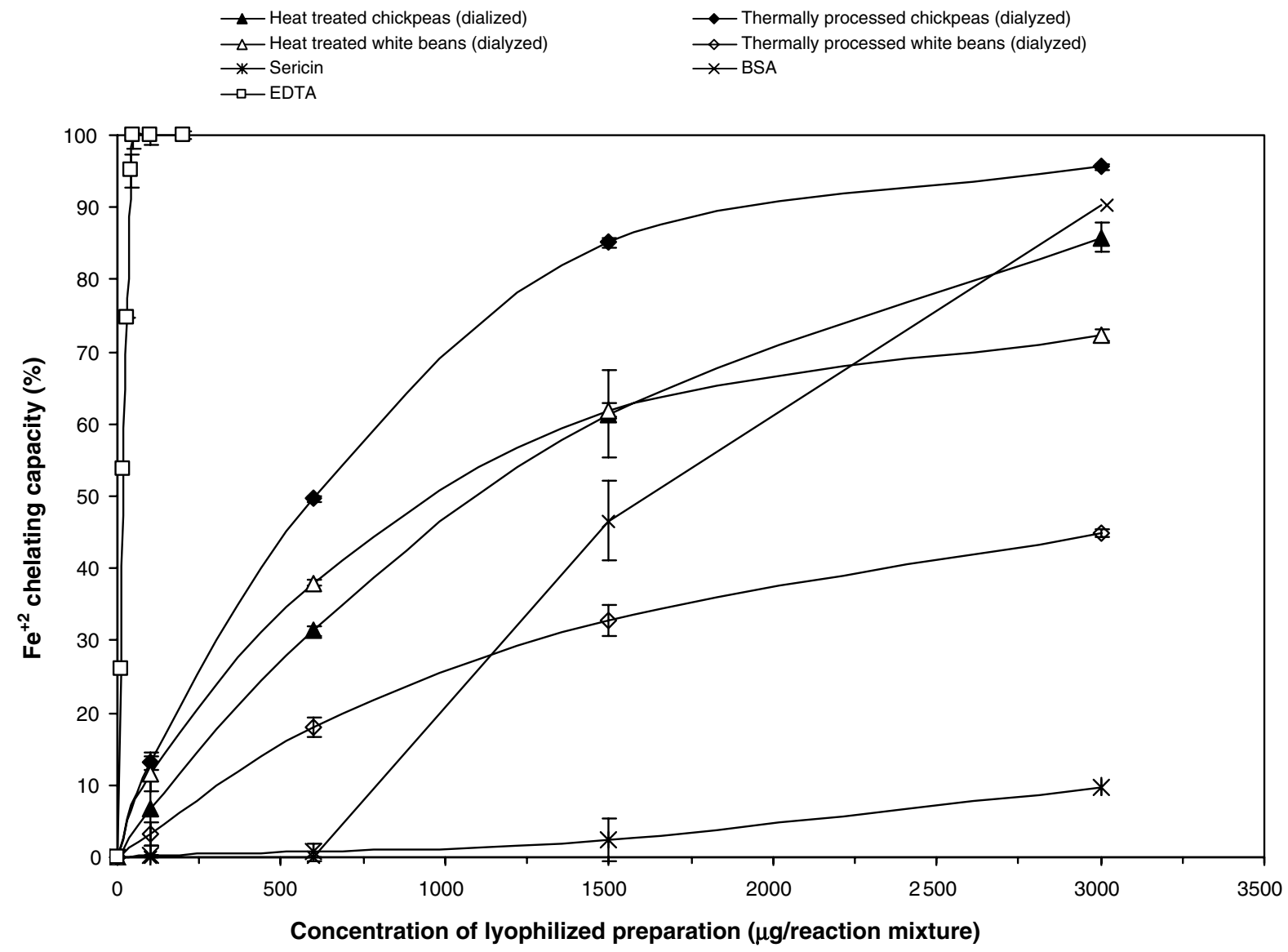

Fig. 3. $\mathrm{Fe}^{+2}$-chelating capacities of different lyophilized protein extracts from heat-treated or thermally processed chickpeas and white beans.

protein extracts showed significantly higher $\mathrm{Fe}^{+2}$ chelating capacity than did BSA (Fig. 3).

\subsection{Ammonium sulfate precipitation of crude protein extracts}

To better understand the effect of thermal processing on antioxidant activity, the crude protein extracts of thermally processed samples were also partially purified by ammonium sulfate precipitation. As seen in Tables 3 and 4, ammonium sulfate precipitation, at $90 \%$ saturation, reduced the yield of antioxidant activity for both chickpea and white bean protein extracts by almost $60 \%$. It seems that the ammonium sulfate did not precipitate most of the antioxidants at the studied saturation or it caused the aggregation of proteins and led to masking of the antioxidant activity. The protein yield from ammonium sulfate precipitation was greater than that for antioxidant activity and occurred at the levels of $54 \%$ and $50 \%$ for chickpea and white bean proteins, respectively. Thus, this caused a drop of specific antioxidant activity in both extracts. In chickpea extracts, the application of dialysis further reduced the yield of antioxidant activity, but the yield of protein did not change significantly. In contrast, in white bean extracts, the application of dialysis reduced yields of both antioxidant activity and protein.

Following dialysis, the ammonium sulfate-precipitated extracts were lyophilized and assayed for protein content.

Table 3

Partial purification of crude protein extracts from thermally processed chickpeas

\begin{tabular}{|c|c|c|c|c|c|c|c|}
\hline Step & Volume (ml) & $\begin{array}{l}\text { Total antioxidant } \\
\text { activity }^{\mathrm{a}}(\mu \text { mol trolox })\end{array}$ & $\begin{array}{l}\text { Total } \\
\text { protein }(\mathrm{mg})\end{array}$ & $\begin{array}{l}\text { Specific antioxidant } \\
\text { activity }(\mu \mathrm{mol} \text { trolox/mg protein) }\end{array}$ & $\begin{array}{l}\text { Yield of antioxidant } \\
\text { activity }(\%)\end{array}$ & Purity (fold) & $\begin{array}{l}\text { Yield of } \\
\text { protein }(\%)\end{array}$ \\
\hline \multicolumn{8}{|c|}{ Crude extract } \\
\hline & 52.5 & 89.5 & 225 & 0.40 & 100 & 1.0 & 100 \\
\hline \multicolumn{8}{|c|}{$90 \%\left(\mathrm{NH}_{4}\right)_{2} \mathrm{SO}_{4}$ precipitation } \\
\hline & 17.5 & 34.6 & 122 & 0.28 & 39 & 0.7 & 54 \\
\hline \multicolumn{8}{|c|}{36 h dialysis at $4{ }^{\circ} \mathrm{C}$} \\
\hline
\end{tabular}

${ }^{\mathrm{a}}$ Trolox equivalents formed in 15 min test period. 
Table 4

Partial purification of crude protein extracts from thermally processed white beans

\begin{tabular}{|c|c|c|c|c|c|c|c|}
\hline Step & Volume (ml) & $\begin{array}{l}\text { Total antioxidant } \\
\text { activity }^{\mathrm{a}}(\mu \mathrm{mol} \text { trolox })\end{array}$ & $\begin{array}{l}\text { Total } \\
\text { protein }(\mathrm{mg})\end{array}$ & $\begin{array}{l}\text { Specific antioxidant } \\
\text { activity ( } \mu \text { mol trolox/mg protein) }\end{array}$ & $\begin{array}{l}\text { Yield of antioxidant } \\
\text { activity }(\%)\end{array}$ & Purity (fold) & $\begin{array}{l}\text { Yield of } \\
\text { protein }(\%)\end{array}$ \\
\hline \multicolumn{8}{|c|}{ Crude extract } \\
\hline & 47 & 65.8 & 152 & 0.43 & 100 & 1.0 & 100 \\
\hline \multicolumn{8}{|c|}{$90 \%\left(\mathrm{NH}_{4}\right)_{2} \mathrm{SO}_{4}$ precipitation } \\
\hline & 26 & 27.8 & 76 & 0.37 & 42 & 0.86 & 50 \\
\hline \multicolumn{8}{|c|}{$36 \mathrm{~h}$ dialysis at $4^{\circ} \mathrm{C}$} \\
\hline & 30 & 19.8 & 49 & 0.40 & 30 & 0.93 & 32 \\
\hline
\end{tabular}

a Trolox equivalents formed in 15 min test period.

Table 5

Purification of antioxidant protein fractions from heat-treated chickpeas

\begin{tabular}{|c|c|c|c|c|c|c|c|}
\hline Step & Volume (ml) & $\begin{array}{l}\text { Total antioxidant } \\
\text { activity }^{\mathrm{a}}(\mu \mathrm{mol} \text { trolox })\end{array}$ & $\begin{array}{l}\text { Total } \\
\text { protein }(\mathrm{mg})\end{array}$ & $\begin{array}{l}\text { Specific antioxidant activity } \\
(\mu \mathrm{mol} \text { trolox/mg protein })\end{array}$ & $\begin{array}{l}\text { Yield of antioxidant } \\
\text { activity }(\%)\end{array}$ & Purity (fold) & Yield of protein $(\%)$ \\
\hline \multicolumn{8}{|c|}{ Crude extract } \\
\hline & 46 & 59 & 171 & 0.35 & 100 & 1.0 & 100 \\
\hline \multicolumn{8}{|c|}{$72 \mathrm{~h}$ dialysis at $4^{\circ} \mathrm{C}$} \\
\hline & 50 & 34 & 126 & 0.27 & 58 & 0.77 & 74 \\
\hline \multicolumn{8}{|c|}{ DEAE-cellulose chromatography } \\
\hline $\mathrm{A}_{1}$ & 35 & 3.7 & 7.6 & 0.49 & 6.3 & 1.40 & 4.4 \\
\hline $\mathrm{A}_{2}$ & 35 & 5.4 & 5.7 & 0.95 & 9.2 & 2.71 & 3.3 \\
\hline $\mathrm{A}_{3}$ & 20 & 3.1 & 9.5 & 0.33 & 5.3 & 0.94 & 5.6 \\
\hline $\mathrm{A}_{4}$ & 25 & 2.4 & 12.5 & 0.19 & 4.1 & 0.54 & 7.3 \\
\hline $\mathrm{A}_{5}$ & 25 & 1.8 & 8.4 & 0.21 & 3.1 & 0.6 & 4.9 \\
\hline
\end{tabular}

a Trolox equivalents formed in 15 min test period.

Table 6

Purification of antioxidant protein fractions from thermally processed chickpeas

\begin{tabular}{|c|c|c|c|c|c|c|c|}
\hline Step & Volume (ml) & $\begin{array}{l}\text { Total antioxidant } \\
\left.\text { activity }^{\mathrm{a}} \text { ( } \mu \text { mol trolox }\right)\end{array}$ & $\begin{array}{l}\text { Total } \\
\text { protein }(\mathrm{mg})\end{array}$ & $\begin{array}{l}\text { Specific antioxidant activity } \\
(\mu \mathrm{mol} \text { trolox/mg protein })\end{array}$ & $\begin{array}{l}\text { Yield of antioxidant } \\
\text { activity }(\%)\end{array}$ & Purity (fold) & Yield of protein $(\%)$ \\
\hline \multicolumn{8}{|c|}{ Crude extract } \\
\hline & 47 & 54 & 155 & 0.35 & 100 & 1.0 & 100 \\
\hline \multicolumn{8}{|c|}{$72 \mathrm{~h}$ dialysis at $4^{\circ} \mathrm{C}$} \\
\hline & 37.5 & 17.5 & 100 & 0.18 & 32 & 0.51 & 65 \\
\hline \multicolumn{8}{|c|}{ DEAE-cellulose chromatography } \\
\hline $\mathrm{B}_{1}$ & 35 & 3.2 & 6.6 & 0.49 & 5.9 & 1.40 & 4.3 \\
\hline $\mathrm{B}_{2}$ & 35 & 20.0 & 29.8 & 0.67 & 37 & 1.91 & 19.2 \\
\hline $\mathrm{B}_{3}$ & 30 & 7.3 & 16.4 & 0.45 & 13.5 & 1.29 & 10.6 \\
\hline
\end{tabular}

a Trolox equivalents formed in 15 min test period.

By ammonium sulfate precipitation, an increase in the protein content of lyophilized preparations was expected. However, the results of protein assays showed that the water-soluble protein contents of lyophilized partially purified extracts were almost the same as those of dialyzed crude extracts (Table 1). It seems that, besides proteins, other major hydrocolloids, such as starch and pectin, were also precipitated by the ammonium sulfate.

\subsection{Free radical-scavenging capacity of lyophilized ammonium sulfate-precipitated protein extracts}

The results of free radical inhibition tests for lyophilized dialyzed crude extracts and ammonium sulfate-precipitated and dialyzed crude extracts from thermally processed chickpeas and white beans showed that the free radicalscavenging capacity was increased by almost $25 \%$ and $100 \%$ by the ammonium sulfate precipitation, respectively (Table 1). Partial purification with ammonium sulfate precipitation and dialysis did not increase the specific antioxidant activity of protein extracts. Thus, increase in the antioxidant activity of lyophilized protein extracts by partial purification may be related to the removal of some oxidation sensitive substances that may reduce the antioxidant groups of proteins during the lyophilization process. The AUC values also indicated the presence of 1.3 -fold higher free radical-scavenging capacity of lyophilized partially purified chickpea protein extracts than the lyophilized par- 
tially purified white bean protein extracts. This result was in line with the antioxidant activity measurements conducted on crude protein extracts. However, it should be noted that the higher antioxidant activity of lyophilized partially purified extracts from thermally processed chickpeas is related to their higher protein content but not to their greater specific antioxidant activity. In the literature, studies related to the effects of heat-treatment or thermal processing, on antioxidant activity of legume proteins are scarce. However, both water-soluble chickpea and white bean antioxidant proteins are much more thermostable than the high molecular weight whey antioxidant proteins that aggregated and lost almost $90 \%$ of their free radicalscavenging activity after mild heating at $70{ }^{\circ} \mathrm{C}$ for $15 \mathrm{~min}$ (Tong et al., 2000). The lyophilized partially purified protein extracts from thermally processed chickpeas and white beans also showed almost 2.8- and 2.1-fold higher free radical-scavenging capacity than did BSA, respectively. However, similarly to the lyophilized crude protein extracts both lyophilized partially purified protein extracts showed lower antioxidant activity than did the sericin.

\subsection{DEAE-cellulose chromatography of dialyzed crude protein extracts}

To increase the purity of antioxidant proteins and to determine the effect of thermal processing on free radical- scavenging activity profile of protein fractions, dialyzed crude protein extracts were applied to DEAE-cellulose fast flow columns. The elution profiles of antioxidant activities and protein contents indicated the presence of five antioxidant fractions $\left(\mathrm{A}_{1}-\mathrm{A}_{5}\right)$ in dialyzed crude protein extracts of heat-treated chickpeas (Fig. 4). Among these fractions, $A_{1}$ is a neutral or cationic fraction, since it was not bound by the DEAE-cellulose anion-exchanger. The four antioxidant protein fractions, $\mathrm{A}_{2}, \mathrm{~A}_{3}, \mathrm{~A}_{4}$ and $\mathrm{A}_{5}$, constitute the antioxidant proteins retained by the DEAE-cellulose column. On the other hand, the elution profiles of antioxidant activities and protein contents indicated the presence of three antioxidant fractions $\left(\mathbf{B}_{1}-\mathbf{B}_{3}\right)$ in dialyzed crude protein extracts of thermally processed chickpeas (Fig. 5). $\mathrm{B}_{1}$ constitutes the unretained antioxidant protein fraction reduced by the thermal processing and $\mathrm{B}_{2}$ and $\mathrm{B}_{3}$ constitute the antioxidant proteins retained by the DEAE-cellulose column. These results clearly showed that the thermal processing reduced the number of antioxidant protein fractions. The thermal processing also slightly reduced the total protein contents of crude protein extracts. Moreover, the increased areas of the protein peaks (almost 20\%) retained by the DEAE-cellulose column for thermally processed chickpea extract suggested that the thermal processing also affected the anion-exchange properties of proteins. On the other hand, in both chromatograms obtained in this study, the elution of the major antioxidant protein frac-

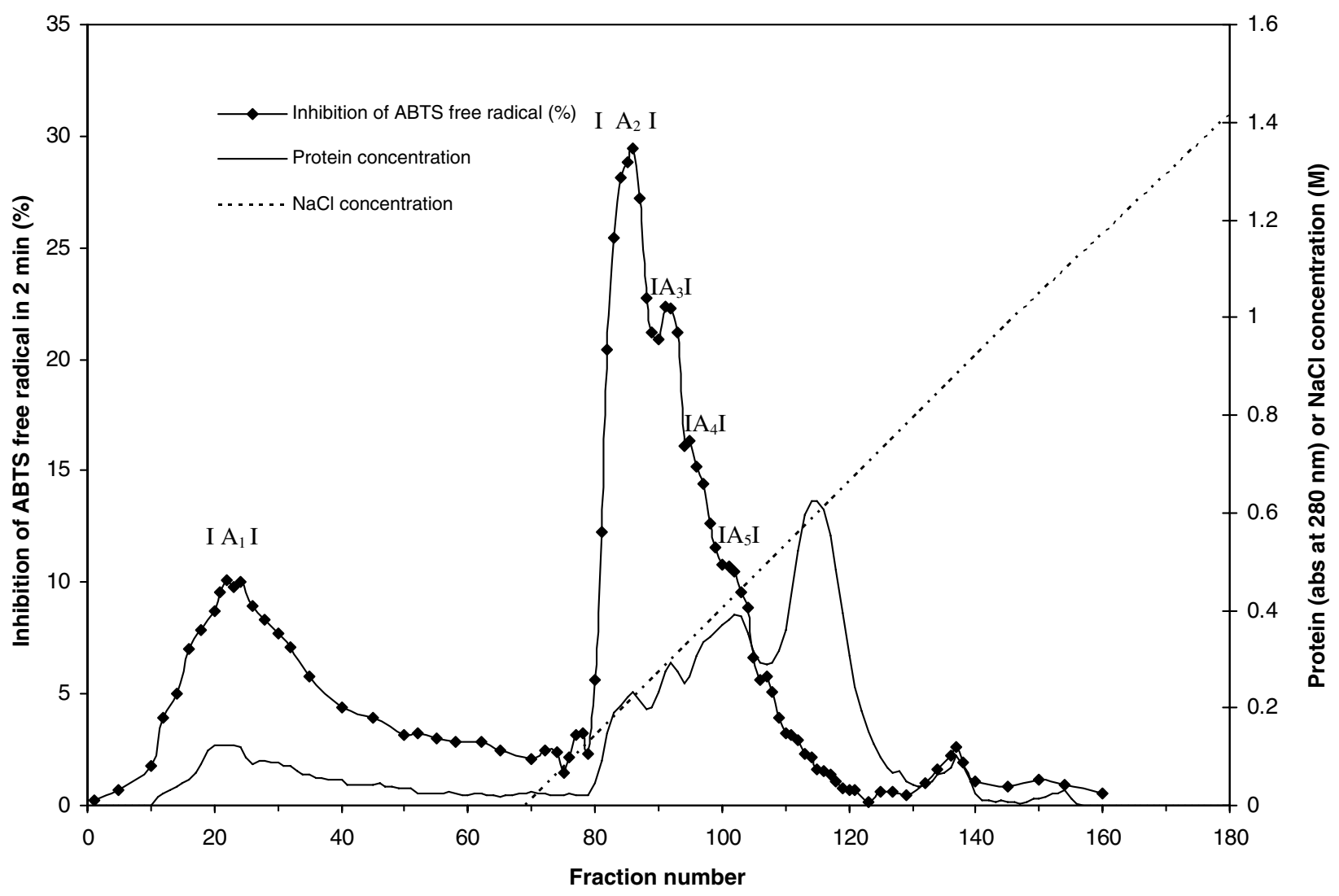

Fig. 4. DEAE-cellulose chromatography of dialyzed protein extract from heat-treated chickpeas. 


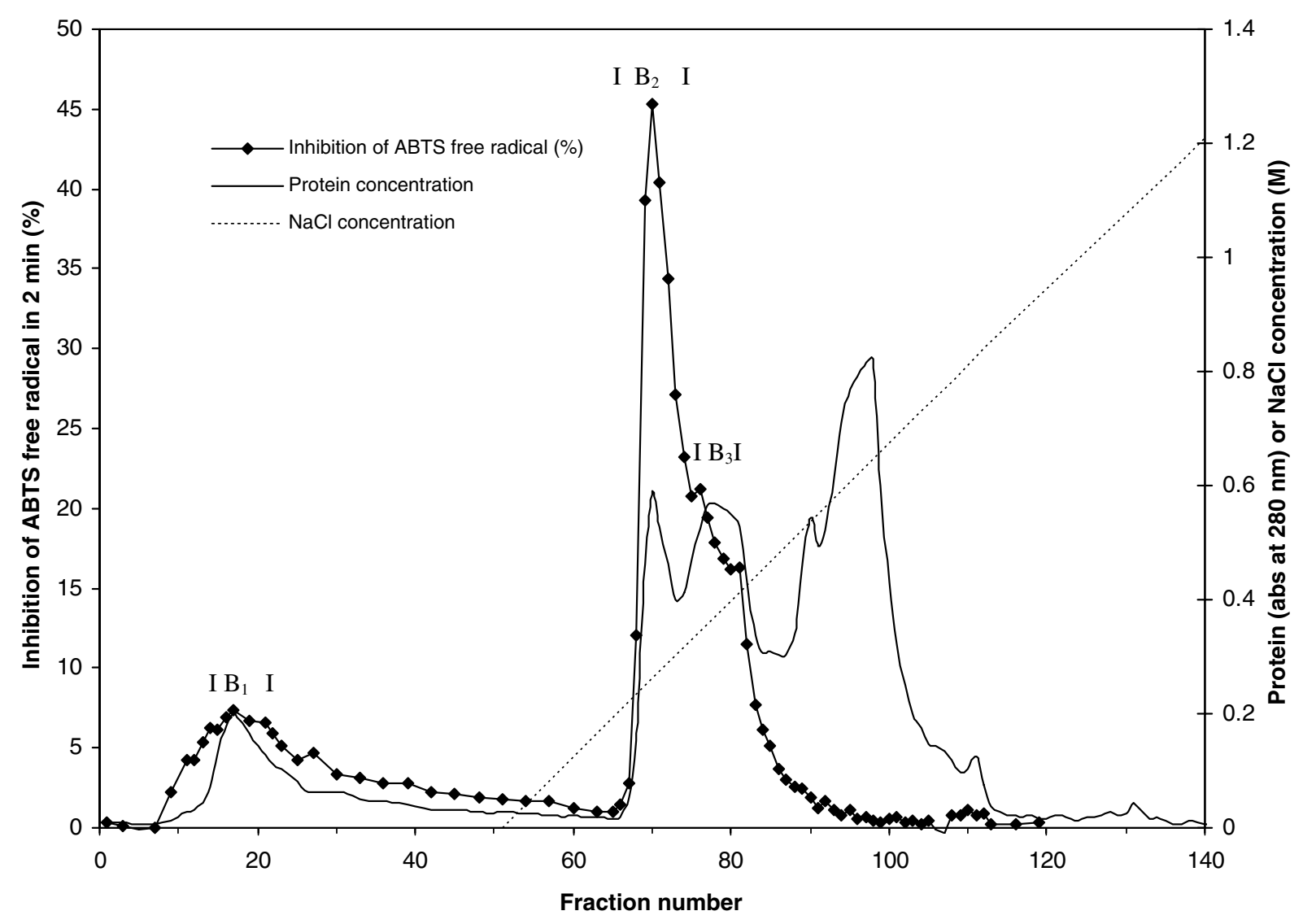

Fig. 5. DEAE-cellulose chromatography of dialyzed protein extract from thermally processed chickpeas.

tions began by the initiation of the linear gradient of $\mathrm{NaCl}$ and ended when $\mathrm{NaCl}$ concentration reached almost $0.5 \mathrm{M}$. The protein peaks, eluted above $0.5 \mathrm{M} \mathrm{NaCl}$ concentration, did not show any marked free radical-scavenging activity. The area of the inhibition vs. fraction number curve obtained for heat-treated chickpea protein extract was almost $25 \%$ greater than the area obtained for the same curve of thermally processed chickpea protein extract. The highest specific antioxidant activities and purification-fold values were obtained for the $\mathrm{A}_{2}$ and $\mathrm{B}_{2}$ fractions from heat-treated and thermally processed chickpeas, respectively (Tables 5 and 6). The high antioxidant activity of these protein fractions may be due to the higher frequency and/or proper positioning of antioxidant amino acids in their sequence. It is also possible that some covalently linked phenolic compounds make a contribution to the free radical-scavenging activity of these proteins. Further studies at the molecular level are needed to understand the exact mechanism of action of antioxidant proteins. However, this study clearly showed that there is a specific group of chickpea proteins associated with the antioxidant activity and these proteins may be fractionated and partially purified by anion-exchange chromatography. It is also interesting to note that, for protein extracts of thermally processed chickpeas, the total amount of antioxidant activity eluted from the DEAE-cellulose column (minimum $31 \mu \mathrm{mol}$ trolox) was higher than the total amount of anti- oxidant activity loaded onto this column $(17.5 \mu \mathrm{mol}$ trolox). It seems that some prooxidants are removed from the protein extracts by DEAE-cellulose chromatography. It is also possible that the partial purification helped in unmasking of the antioxidant activity of proteins. In the literature, there are very few studies related to fractionation of antioxidant proteins from legumes. In fact, the only study determined was that of Okada and Okada (1998) who demonstrated the presence of two antioxidant albumin fractions in broad beans.

\subsection{Free radical-scavenging capacity of lyophilized main antioxidant protein fractions separated by DEAE-cellulose chromatography}

The free radical-scavenging activities of the main antioxidant fractions $\left(\mathrm{A}_{2}\right.$ and $\left.\mathrm{B}_{2}\right)$ were also determined following lyophilization. The free radical-scavenging capacity of $\mathrm{A}_{2}$, obtained from heat-treated chickpeas, was found almost $40 \%$ higher than that of $\mathrm{B}_{2}$, obtained from thermally processed chickpeas (Table 1). However, it should be noted that the amount of protein (almost $29.8 \mathrm{mg}$ before lyophilization) and lyophilized sample (almost $32 \mathrm{mg}$ ) of $B_{2}$ was almost 5and 3 -fold higher than those of $\mathrm{A}_{2}$, respectively. The $\mathrm{A}_{2}$ and $B_{2}$ fractions showed almost 3.8-and 2.7-fold higher free radical-scavenging capacity than did BSA, respectively. The $\mathrm{A}_{2}$ fraction also showed almost the same free radical- 
scavenging capacity as sericin, whereas $\mathrm{B}_{2}$ showed $66 \%$ of the free radical-scavenging capacity of sericin.

\section{Conclusions}

This study clearly showed the higher free radicalscavenging capacities of soluble proteins from chickpeas than those from white beans. The water-soluble chickpea antioxidant proteins are also much more thermostable than the water-soluble white bean antioxidant proteins and their free radical scavenging and $\mathrm{Fe}^{+2}$-chelating capacities were maintained and improved following thermal processing. Dialysis increased the water-soluble protein content of lyophilized chickpea extracts but it did not significantly affect the water-soluble protein content of lyophilized white bean extracts. Ammonium sulfate precipitation is not effective for the selective precipitation of antioxidant protein fractions. However, anion-exchange chromatography may be used for the partial purification of antioxidant proteins from heat-treated or thermally processed chickpea protein extracts. The results of this work show the good potential of soluble chickpea proteins as natural thermostable food antioxidants. Further screening of different chickpea cultivars for soluble protein content, antioxidant activity and thermostability is needed for selection of suitable cultivars.

\section{Acknowledgements}

This project was funded mainly by the Research Foundation of the Izmir Institute of Technology (Project \# 2004 IYTE 05). Also, partial support was obtained from the related MISAG \# 221 project of The Scientific and Technical Research Council of Turkey (TÜBITTAK).

\section{References}

Aime, S., Digilio, G., Bruno, E., Mainero, V., Baroni, S., \& Fasano, M. (2003). Modulation of the antioxidant activity of HO scavengers by albumin binding: A ${ }^{19}$ F-NMR study. Biochemical and Biophysical Research Communications, 307, 962-966.

Al-Malah, K. I., Azzam, M. O. J., \& Omari, R. M. (2000). Emulsifying properties of BSA in different vegetable oil emulsions using conductivity technique. Food Hydrocolloids, 14, 485-490.

Bhatty, R. S. (1982). Albumin proteins of eight grain legume species: Electrophoretic patterns and amino acid composition. Journal of Agricultural and Food Chemistry, 30, 620-622.

Burnett, G., Rigby, N. M., Mills, E. N. C., Belton, P. S., Fido, R. J., Tatham, A. S., et al. (2002). Characterization of the emulsification properties of $2 \mathrm{~S}$ albumins from sunflower seed. Journal of Colloid and Interface Science, 247, 177-185.

Chen, H., Muramoto, K., \& Yamauchi, F. (1995). Structural analysis of antioxidative peptides from soybean $\beta$-conglycinin. Journal of Agricultural and Food Chemistry, 43, 574-578.

Chen, H., Muramoto, K., Yamauchi, F., \& Nokihara, K. (1996). Antioxidant activity of designed peptides based on the antioxidative peptide isolated from digests of a soybean protein. Journal of Agricultural and Food Chemistry, 44, 2619-2623.

Chen, H., Muramoto, K., Yamauchi, F., Fujimoto, K., \& Nokihara, K. (1998). Antioxidative properties of histidine-containing peptides designed from peptide fragments found in the digests of a soybean protein. Journal of Agricultural and Food Chemistry, 46, 49-53.
Chiue, H., Kusano, T., \& Iwami, K. (1997). Deamidation-induced fragmentation of maize zein, and its linked reduction in fatty acidbinding capacity as well as antioxidative effect. Food Chemistry, 58, 111-117.

Damodaran, S. (1996). Amino acids, peptides and proteins. In O. R. Fennema (Ed.), Food Chemistry (pp. 321-429). New York: Marcel Decker Inc.

Freidman, M. (1996). Nutritional value of proteins from different food sources. A review. Journal of Agricultural and Food Chemistry, 44, 6-29.

Fukuzawa, K., Saitoh, Y., Akai, K., Kogure, K., Ueno, S., Tokumura, A., et al. (2005). Antioxidant effect of bovine serum albumin on membrane lipid peroxidation induced by iron chelate and superoxide. Biochimica et Biophysica Acta, 1668, 145-155.

Garcia, E., Filisetti, T. M. C. C., Udaeta, J. E. M., \& Lajolo, F. M. (1998). Hard to-cook beans (Phaseolus vulgaris): Involvement of phenolic compounds and pectates. Journal of Agricultural and Food Chemistry, 46, 2110-2116.

Genovese, M. I., \& Lajolo, F. M. (1998). Influence of naturally acidsoluble proteins from beans (Phaseolus vulgaris L.) on in vitro digestibility determination. Food Chemistry, 62, 315-323.

Harris, D. A. (1987). Spectrophotometric assays. In D. A. Harris \& C. L. Bashford (Eds.), Spectrophotometry and spectrofluorometry (pp. 59-60). Oxford: I.R.L. Press.

Hernandez-Infante, M., Sousa, V., Montalvo, I., \& Tena, E. (1998). Impact of microwave heating on hemagglutinins, tyripsin inhibitors and protein quality of selected legume seeds. Plant Foods for Human Nutrition, 52, 199-208.

Hou, W., Lee, M., Chen, H., Liang, W., Han, C., Liu, Y., et al. (2001). Antioxidant activities of dioscorin, the storage protein of yam (Dioscorea batatas Decne) tuber. Journal of Agricultural and Food Chemistry, 49, 4956-4960.

Huang, S., Satue-Gracia, M. T., Frankel, E. N., \& German, J. B. (1999). Effect of lactoferrin on oxidative stability of corn oil emulsions and liposomes. Journal of Agricultural and Food Chemistry, 47, 1356-1361.

Hu, M., McClements, D. J., \& Decker, E. A. (2003). Lipid oxidation in corn oil-in-water emulsions stabilized by casein, whey protein isolate, and soy protein isolate. Journal of Agricultural and Food Chemistry, 51, 1696-1700.

Je, J., Park, P., \& Kim, S. (2004). Antioxidant activity of a peptide isolated from alaska pollack (Theragra chalcogramma) frame protein hydrolysate. Food Research International, 52, 7842-7845.

Khan, M. A. S., Nakamura, S., Ogawa, M., Akita, E., Azakami, H., \& Kato, A. (2000). Bactericidal action of egg yolk phosvitin against Escherichia coli under thermal stress. Journal of Agricultural and Food Chemistry, 48, 1503-1506.

Kouoh, F., Gressier, B., Luyckx, M., Brunet, C., Dine, T., Cazin, M., et al. (1999). Antioxidant properties of albumin: Effect on oxidative metabolism of human neutrophil granulocytes. Il Farmaco, 54, 695-699.

Le Tien, C., Vachon, C., Mateescu, M. A., \& Lacroix, M. (2001). Milk protein coatings prevent oxidative browning of apples and potatoes. Journal of Food Science, 66, 512-516.

Liceaga-Gesualdo, A., Li-Chan, E. C. Y., \& Skura, B. J. (2001). Antimicrobial effect of lactoferrin digest on spores of a Penicillium sp. isolated from bottled water. Food Research International, 34, 501-506.

Liu, Y., Han, C., Lee, M., Hsu, F., \& Hou, W. (2003). Patatin, the tuber storage protein of potato (Solanum tuberosum L.), exhibits antioxidant activity in vitro. Journal of Agricultural and Food Chemistry, 51, 4389-4393.

Ma, C., \& Harwalkar, R. (1984). Chemical characterization and functionality assessment of oat protein fractions. Journal of Agricultural and Food Chemistry, 32, 144-149.

Maheswari, S. U., Ramadoss, C. S., \& Krishnaswamy, P. R. (1997). Inhibition of $\mathrm{Fe}$ (II) catalyzed linoleic acid oxidation and DNA damage by phosvitin. Molecular and Cellular Biochemistry, 177, $47-51$. 
Moore, M. E., Han, I. Y., Action, J. C., Ogale, A. A., Barmore, C. R., \& Dawson, P. L. (2003). Effects of antioxidants in polyethylene film on fresh beef color. Journal of Food Science, 68, 99-104.

Okada, Y., \& Okada, M. (1998). Scavenging effect of water soluble proteins in broad beans on free radicals and active oxygen spices. Journal of Agriculture and Food Chemistry, 46, 401-406.

Pearce, K. N., \& Kinsella, J. E. (1978). Emulsifying properties of proteins: Evaluation of a turbidimetric technique. Journal of Agricultural and Food Chemistry, 26, 716-723.

Rajalakshmi, D., \& Narasimhan, S. (1996). Food antioxidants: Sources and methods of evaluation. In D. L. Madhavi, S. S. Deshpande, \& D. K. Salunke (Eds.), Food antioxidants (pp. 65-157). New York: Marcel Dekker, Inc.

Rajapakse, N., Mendis, E., Jung, W., Je, J., \& Kim, S. (2005). Purification of a radical scavenging peptide from fermented mussel sauce and its antioxidant properties. Food Research International, 38, 175-182.

Recio, I., \& Visser, S. (2000). Antibacterial and binding characteristics of bovine, ovine and caprine lactoferrins: A comparative study. International Dairy Journal, 10, 597-605.

Re, R., Pellegrini, N., Proteggente, A., Pannala, A., Yang, M., \& RiceEvans, C. (1999). Antioxidant activity applying an improved ABTS radical cation decolorization assay. Free Radical Biology and Medicine, 26, 1231-1237.

Rocha, M. C. P., Genovese, M. I., \& Lajolo, F. M. (2002). Albumins from the bean Phaseolus vulgaris: Effects of heat treatment. Journal of Food Biochemistry, 26, 191-208.

Saiga, A., Tanabe, S., \& Nishumura, T. (2003). Antioxidant activity of peptides obtained from porcine myofibrillar proteins by protease treatment. Journal of Agricultural and Food Chemistry, 51, 3661-3667.

Saini, H. S., \& Knights, E. J. (1984). Chemical constitution of starch and oligosaccharide components of "Desi" and "Kabuli" chickpea (Cicer arietinum) seed types. Journal of Agricultural and Food Chemistry, 32, 940-944.
Sanchez-Mata, M. C., Penuela-Teruel, M. J., Camara-Hurtado, M., DiezMarques, C., \& Torija-Isasa, M. E. (1998). Determination of mono-, di- and oligosaccharides in legumes by high-performance liquid chromatography using an amino-bounded silica column. Journal of Agricultural and Food Chemistry, 46, 3648-3652.

Satue-Gracia, M. T., Frankel, E. N., Rangavajhyala, N., \& German, J. B. (2000). Lactoferrin in infant formulas: Effect on oxidation. Journal of Agricultural and Food Chemistry, 48, 4984-4990.

Tong, L. M., Sasaki, S., McClements, D. J., \& Decker, E. A. (2000). Mechanisms of the antioxidant activity of a high molecular weight fraction of whey. Journal of Agricultural and Food Chemistry, 48, 1473-1478.

Vermeiren, L., Devlieghere, F., van Beest, M., de Kruijf, N., \& Debevere, J. (1999). Developments in the active packaging of foods. Trends in Food Science and Technology, 10, 77-86.

Wolosiak, R., \& Klepacka, M. (2002). Antioxidative properties of albumins in enzymatically catalyzed model systems. Electronic Journal of Polish Agricultural Universities, Series: Food Science and Technology, 5, 1. Available fromhttp://www.eipau.media.pl.

Wu, Y., Weller, C. L., Hamouz, F., Cuppett, S., \& Schnepf, M. (2001). Moisture loss and lipid oxidation for precooked ground-beef patties packaged in edible starch-alginate-based composite films. Journal of Food Science, 65, 486-493.

Yamada, H. F., Fuwa, N. F., \& Nomura, M. T. (2000). Use of sericin as antioxidants and tyrosinase inhibitors. United States Patent Documents. Patent No: 6,165,982.

Yemenicioğlu, A., Özkan, M., Velioğlu, S., \& Cemeroğlu, B. (1998). Thermal inactivation kinetics of peroxidase and lipoxygenase from fresh pinto beans (Phaseolus vulgaris). Zeitschrift für LebensmittelUntersuchung und -Forschung A, 206, 294-296.

Zhao, L., Zhao, G., Hui, B., Zhao, Z., Tong, J., \& Hu, X. (2004). Effect of selenium on increasing the antioxidant activity of protein extracts from a selenium-enriched mushroom species of the Genoderma Genus. Journal of Food Science, 69, 184-188. 